\title{
CHILDREN'S RIGHTS IN THE BILL OF RIGHTS: MEETING OR EXCEEDING INTERNATIONAL STANDARDS?
}

\author{
Dr Ursula Kilkelly, Lecturer, Faculty of Law, University College \\ Cork
}

\section{INTRODUCTION}

A Bill of Rights reflecting the particular circumstances of Northern Ireland was envisaged under the Belfast Agreement 1998 as a piece of the jigsaw that would form part of a lasting settlement. ${ }^{1}$ In this context, it is vital that the Bill of Rights, which is designed to help create the foundation upon which the future of Northern Ireland can be built, set out the rights of children, to whom this future belongs. Including children's rights in the Bill of Rights is not a matter of choice, therefore, as any attempt to close the book on the injustices suffered during Northern Ireland's violent past must recognise that both directly and indirectly, it is children who have suffered the most by growing up knowing only a divided and conflict ridden society. These are the particular circumstances of Northern Ireland. More generally, however, children are recognised worldwide, as the largest voiceless minority; they are vulnerable to exploitation and abuse and they are incapable of influencing directly political and administrative decision making. ${ }^{2}$ The need to recognise and protect their rights has been pursued at international level since 1924. ${ }^{3}$ These objectives have become universal through the widespread ratification of the United Nations Convention on the Rights of the Child. ${ }^{4}$

The Human Rights Commission's support for these views is apparent from its preliminary proposals on a Bill of Rights for Northern Ireland, which contain a chapter dedicated to the rights of children, in addition to other relevant chapters on the family and education. This paper asks to what extent do the Commission's proposals on children's rights meet international standards, and goes on to consider what is required to exceed them.

\section{THE SOURCE OF INTERNATIONAL STANDARDS}

In drafting a Bill of Rights for the particular circumstances of Northern Ireland, it is important to draw on international human rights instruments. ${ }^{5}$

1 Agreement Reached in the Multi-Party Negotiations, April 10 1998, at pp 16-17. See also s 69(7) Northern Ireland Act 1998, chap 47.

2 Office of the First Minister and Deputy First Minister, Protecting our Children's Rights: A Consultation Paper on a Commissioner for Children for Northern Ireland (2001), p 9.

3 Declaration on the Rights of the Child was adopted by the League of Nations in 1924.

4 UN Doc A/44. The UN Convention on the Rights of the Child was adopted by the General Assembly on November 20th, 1989. It has been ratified by 191 states with the exception of the United States of America and Somalia.

5 Indeed, this approach is expressly set out in the Agreement, see note 1, at p 17. 
For this purpose, international law can be divided into those treaties which deal exclusively with children's rights and those which mainstream children's rights issues into general human rights treaties.

The most important treaty of the former kind is the internationally binding UN Convention on the Rights of the Child, 1989, which sets out comprehensively the rights to which children are entitled in all areas of their lives. In addition to its many detailed and varying provisions, it establishes a number of universal principles, such as Article 12 which enshrines the child's right to be heard and Article 3 which provides that the child's best interests shall be a primary consideration in all actions taken regarding children. The Convention's dedication to the rights of children and almost universal ratification have facilitated its use as a benchmark against which the implementation of children's rights can be measured. ${ }^{6}$ Indeed, its standards have been used to inform the case law of the European Court of Human Rights ${ }^{7}$ and have raised the profile of children's issues at national and international levels. ${ }^{8}$ In light of the fact that some of its standards, which were set by consensus to achieve universality, are considered to be too low ${ }^{9}$ it is significant that the provisions of the Children's Convention are informed by a number of more detailed standards dealing with children's rights in specific areas. Important examples include the UN Rules for the Protection of Juveniles Deprived of their Liberty ${ }^{10}$, the UN Standard Minimum Rules for the Administration of Juvenile Justice (the Beijing Rules) ${ }^{11}$ and various ILO conventions on child labour. ${ }^{12}$ Moreover, the UN Committee on the Rights of the Child - the expert body which monitors implementation - has begun to make General Comments which provide further detail as to how the Convention is to be interpreted ${ }^{13}$ and has organised Discussion Days on its application in certain areas, including children and the media, children with

6 See Geraghty, Getting it Right? An evaluation of the UK Government's Implementation of the UN Convention on the Rights of the Child in Northern Ireland 1994-1999 (1999).

7 See U. Kilkelly, "The Best of Both Worlds for Children's Rights? Interpreting the European Convention on Human Rights in the Light of the UN Convention on the Rights of the Child", (2001) 23(2) Human Rights Quarterly 308.

8 See further Fottrell (ed) Revisiting Children's Rights: 10 Years of the UN Convention on the Rights of the Child (2000).

9 In recognition of this fact, the Convention's standards have been raised by Optional Protocol on two occasions. The Optional Protocol on the involvement of children in armed conflicts was adopted by the General Assembly Resolution A/RES/54/263 of 25 May 2000 (it enters into force on 13 February 2002) and the Optional Protocol on the sale of children, child prostitution and child pornography was adopted by General Assembly Resolution A/RES/54/263 of 25 May 2000 (it enters into force on 18 January 2002).

10 These Rules were adopted by General Assembly Resolution 45/113 of 14 December 1990.

11 The Beijing Rules were adopted by the General Assembly Resolution 40/33 of 29 November 1985.

12 See, for example, ILO 138 Convention concerning the Minimum Age for Admission to Employment, 1973 and ILO 182 Convention concerning the Prohibition and Immediate Action for the Elimination of the Worst Forms of Child Labour, which came into force on 19 November 2000.

13 See General Comment No 1 The Aims of Education, CRC/GC/2001/1, CRC 17 April 2001. 
disabilities, youth justice and the role of the family. ${ }^{14}$ Furthermore, the Committee's observations and recommendations on the efforts which individual states like the UK have undertaken to implement children's rights provide a unique analysis of the extent to which the Convention has been implemented at national level. ${ }^{15}$

In addition to this wealth of material, children's rights can be found in other general instruments of the United Nations and the Council of Europe. For example, both the International Covenant on Civil and Political Rights, $1966^{16}$ and the International Covenant on Economic, Social and Cultural Rights, $1966^{17}$ contain separate provisions on the rights of children, as well as references in other provisions to the child's right to special protection. The Council of Europe's Social Charter contains a provision dedicated to the right of children and young persons to protection ${ }^{18}$ and the case law of the Commission and Court of Human Rights has provided positive but sporadic evidence of the protection that the European Convention on Human Rights offers children. ${ }^{19}$ There also exists a whole range of decisions, declarations and advisory opinions on children's rights by bodies like the UN Economic and Social Council, ${ }^{20}$ and the Parliamentary Assembly and the Committee of Ministers of the Council of Europe. ${ }^{21}$ UK specific recommendations made by treaty monitoring bodies like the Human Rights Committee ${ }^{22}$ and the Council of Europe Committee for the Prevention of Torture ${ }^{23}$ provide a

14 For full details of all of the Committee's discussion days see CRC/C/DOD/1 19 September 2001.

15 See Consideration of reports submitted by states parties under Article 44 of the Convention: United Kingdom of Great Britain and Northern Ireland. 15/02/95 CRC/C/15/Add.34 (Concluding Observations).

16 ICCPR adopted by the General Assembly on 16 December 1966, 999 UNTS 171. The ICCPR has a separate provision concerning the rights of children (Article 24) and the family (Article 23) as well as a references to children's rights in other provisions, such as Article 10 on detention and Article 14 on criminal justice.

17 ICESCR adopted by the General Assembly on 16 December 1966. Article 10 is concerned with the family and the rights of children and Article 13 deals with the right to education.

18 Article 7, ETS No 38. The Charter was signed on 18 October 1961 and was revised in 1996.

19 See U. Kilkelly, The Child and the European Convention on Human Rights (1999).

20 See, for example, the resolutions of the Commission on Human Rights of ECOSOC on human rights in the administration of juvenile justice in 1996 (E/CN.4/RES/1996/32), 1998 (E/CN.4/RES/1998/39) and 2000 (E/CN.4/RES/2000/39).

21 See, for example, Recommendation 2001 (16) of the Committee of Ministers on the protection of children from sexual exploitation, adopted on 31 October 2001. For details of other recommendations and decisions passed by the Council of Europe see Council of Europe The Rights of the Child: A European Perspective (1996).

22 Concluding Observations of the Human Rights Committee: United Kingdom of Great Britain and Northern Ireland. 05/11/2001. CCPR/CO/73/UK, CCPR/CO/73/UKOT.

23 Report to the Government of the United Kingdom on the visit to Northern Ireland carried out by the European Committee for the Prevention of Torture and Inhuman and Degrading Treatment or Punishment (CPT) from 29 Nov to 8 Dec 1999 
further useful indicator of the extent to which the UK is implementing its treaty obligations in Northern Ireland with respect to treaties such as the International Covenant on Civil and Political Rights and the Convention for the Prevention of Torture and Inhuman or Degrading Treatment or Punishment. ${ }^{24}$ Taken together these documents highlight the level of rights protection which the UK is obliged to put in place. They also provide evidence of the extent to which children's rights are protected in domestic law, policy and practice in Northern Ireland, and accordingly assist in the identification of gaps in the protection of children's rights, which the Bill of Rights might attempt to fill.

\section{CHILDREN'S RIGHTS IN THE PROPOSED BILL OF RIGHTS}

There follows an evaluation of the extent to which the provisions of the proposed Bill of Rights reflect these international standards. First, however, it is necessary to consider the approach taken by the Human Rights Commission in providing for children's rights in its proposals.

\section{(a) The approach: specific versus general provision}

International law provides examples of the two main approaches open to the Commission in providing for children's rights in the Bill of Rights for Northern Ireland. The first option is to mainstream the children's rights standards, or to incorporate them completely into the general human rights provisions. An admittedly poor example of this is the European Convention on Human Rights, which limits its references to children to general provisions on the right to liberty and fair trial in Articles 5 and 6, and thus contains no dedicated children's rights provision. While this approach may serve to reinforce the application of all rights to children, it offers limited potential for the recognition of those rights which are exclusive to children. The second option - and the one chosen by the Commission in the Bill of Rights - is to have a dedicated children's rights provision, which sets out all the rights enjoyed exclusively by children. The international equivalent here is the Convention on the Rights of the Child, which contains only those standards relevant to children. The disadvantage with this approach is that it threatens to isolate the children's rights standards in a way which may undermine the applicability to children of all the rights recognised. It appears, therefore, that a combination of these approaches would maximise the potential of the Bill of Rights to improve the situation for children in Northern Ireland. Accordingly, the mainstreaming of children's rights would thus take place where appropriate, and a dedicated children's rights provision would deal with the remaining rights, which are exclusive to children. The objective of such an approach would be to include children's rights in the

(CPT/Inf/(2001) 6) and Government Response to the CPT Report, CPT/Inf (2001) 7. Both can be found at www.cpt.coe.int

${ }^{24}$ See also the Concluding Observations of the Committee on the Elimination of Racial discrimination: United Kingdom of Great Britain and Northern Ireland 23/04/97 CERD/C/304/Add.20, the Concluding observations of the Committee on Economic, Social and Cultural Rights: United Kingdom of Great Britain and Northern Ireland. 21/12/94. E/C.12/1994/19 and Concluding Observations of the Committee on the Elimination of Discrimination Against Women: United Kingdom of Great Britain and Northern Ireland, 01/07/99 
Bill of Rights in a coherent way, which both recognises the importance of child-specific rights while reinforcing the application of all other, general rights to children.

\section{(b) The content}

Chapter 10 of the Commission's Consultation document contains the provision dedicated exclusively to children's rights in the proposed Bill of Rights ${ }^{25}$ which mirrors to a large extent the proposals of the Working Group on Children's Rights. ${ }^{26}$

Article 10 contains 11 sections dealing with the following areas of children's rights:

1. general provisions

2. participation rights

3. the family

4. protection rights

5. children in conflict with the law

6. children with disabilities

7. right to play

8. health care

9. education

10. children's economic rights

11. rights awareness

The italics identify those provisions, which could reasonably be incorporated into the main provisions dealing with the areas of criminal justice, health care, education, and social, economic and environmental rights respectively. This process would see the reassignment of about half of these sections to their more natural homes and a considerable strengthening of the general provisions would take place as a result. Furthermore, the rights of children with disabilities could be integrated into a new mainstream provision on this issue, curiously absent from the Commission's preliminary proposals.

The dedicated section on the family in Chapter 9 of the Commission's Consultation Document sits strangely apart from the children's rights provision, although the intention is clearly to incorporate Article 8 European Convention on Human Rights into the Bill of Rights. It makes little sense, however, to separate Article 8 from the family section in Chapter 10, particularly given that emphasis on the child in care dominates both the latter and the case law of the European Court of Human Rights, to which the

25 Northern Ireland Human Rights Commission, Making a Bill of Rights for Northern Ireland: A Consultation by the Northern Ireland Human Rights Commission (2001), pp 62-71.

26 The report of the working Group can be found on the Human Rights Commission's website at www.nihrc.org. 
reference to Article 8 relates. ${ }^{27}$ Consolidation of these provisions would be more coherent and effective, and in this context, consideration might also be given to reflecting the principles of Article 8 case law either generally, or with specific reference to the right of relevant parties to participate in the decision making process concerning the family; the principle of the right of the child to be returned to his/her family once state care is no longer necessary and the right of family members to mutual contact, for example.

In any event, this appropriate mainstreaming of children's rights would leave the dedicated children's rights provision to deal only with those substantive rights exclusive to children. Its content would thus include: general provisions; participation rights; the right to protection; the right to play and rights awareness. It is submitted that the provisions on the right to protection, play and the right to information about rights adequately reflect international standards. The remaining part of this paper will thus address the issues of guiding principles and general provisions.

\section{(c) General provisions}

\section{Scope of Protection}

The proposed Article 10(a) has three clauses, the first of which defines a child as everyone under 18 years. This reflects the highest standard in international law.

\section{Best Interests}

The second clause reads as follows:

In all actions concerning children, whether undertaken by public or private institutions, individuals or bodies, courts of law, administrative or legislative authorities, the best interests of the child shall be the paramount consideration and the following rights shall be interpreted as subject to that requirement. (emphasis mine)

This clause is almost identical to Article 3 of the Convention on the Rights of the Child, with one important limitation. Although it sets out the higher domestic standard of requiring the child's best interests to be "the paramount" rather than "a primary" consideration ${ }^{28}$ in all actions concerning children, the clause limits the application of the principle by adding the phrase italicised. The apparent effect of this is not to require the principle to guide action in areas which do not affect rights in Article 10. Yet, the important thing about Article 3 of the Convention on the Rights of the Child, despite its lower standard, is that it is widely applicable to state action in all areas concerning children and it is thus not limited, in a similar manner, to the exercise of Convention rights - although even if it were, the comprehensive nature of the Children's Convention would mean that this would not seriously undermine the principle. To ensure compatibility with the Article 3 principle, this latter clause should be removed from the proposed Article 10 section a, sub-section 2.

27 See Kilkelly, see note 19, pp 263-294.

28 This test is set out in Article 3 Children (Northern Ireland) Order 1995. 


\section{Implementation provision}

The third paragraph in section (a) provides that

Public bodies shall carry out their functions in relation to children in accordance with the provisions of the UN Convention on the Rights of the Child and shall in addition take all reasonable steps to ensure for all children the following rights. (emphasis mine)

There are a number of difficulties with this provision. First, it places two distinct obligations on public authorities with regard to the Children's Convention and the Bill of Rights respectively. The obligations - to carry out functions and take steps to guarantee rights to children - do not apply to both sources of children's rights and thus the obligation to implement children's rights does not apply to the Convention on the Rights of the Child, and vice versa. This approach is divisive and confusing at best, and insofar as it does not compel implementation of the Convention on the Rights of the Child is a wasted opportunity to reaffirm the importance of this Convention at national level. The current situation thus falls short of international standards, although they would be exceeded by extending both obligations to act compatibly with and to implement the provisions of the Convention on the Rights of the Child and the Bill of Rights.

A second difficulty with the obligation contained in this provision, however, is the fact that it requires authorities only to take steps that are "reasonable" to guarantee the rights in Chapter 10 to children. The equivalent provision in the Convention on the Rights of the Child (Article 4) requires states to do what is "appropriate" to implement children's rights and it permits states to use the defence of resources only with regard to economic, social and cultural rights. Moreover, the Committee on the Rights of the Child has encouraged the use of the best interests principle to determine decisions regarding the allocation of resources. ${ }^{29}$ The recommendations of the Working Group had included neither the limitation of "reasonableness", nor resources. Meeting the international standard here, therefore, would require replacing the reference to what is "reasonable" with the word "appropriate". Greater ambitions to exceed the international standard would be fulfilled by removing the limitation altogether. The question of resources, which arguably lies behind the "reasonableness" requirement, should be dealt with in a general Bill of Rights provision on limitations, although extreme caution should be exercised about legitimising an approach according to which rights are protected when, and to the extent to which, resources permit.

\section{(d) Guiding principles}

According to the Committee on the Rights of the Child, three principles must guide the implementation of children's rights in all areas - nondiscrimination; best interests of the child and the child's right to be heard. Only one of these is included in the Commission's proposals on interpretive clauses in the section (a) of Article 10, however, and it is, consequently, the weakest part of the children's rights provision.

29 See Committee on the Rights of the Child, see note 15, at para 24. 


\section{Non-Discrimination: a principle with specific importance for children}

While the principle of non-discrimination is enshrined elsewhere in the Bill of Rights, where the prohibited grounds include "age", nothing in the Bill of Rights reinforces the right of all children to equal treatment and the right to enjoy their rights without discrimination. Thus, laws, policies and procedures which have a detrimental and discriminatory effect on certain groups of children including children with disabilities, Traveller children, children from low income or unmarried families are unaddressed here. In order to reflect the standard set by Article 2 of the Convention on the Rights of the Child and the concerns of the Committee on the Rights of the Child in this area, ${ }^{30}$ it is necessary to include a child-specific principle of nondiscrimination in Chapter 10.

\section{Child's right to be heard: a guiding principle}

The absence from the interpretive provision of Article 10 of the fundamental principle of the child's right to be heard does not meet the international standard set by the Convention or the Committee on the Rights of the Child. ${ }^{31}$ While this right is set out in the main part of the children's rights provision (paragraph b) its elevation to interpretive status is necessary to acknowledge its fundamental character and to reinforce the applicability of the right to all areas of the child's life, including education, care, justice and health.

\section{Child's right to special protection: significant omission}

The most fundamental omission from this section, however, despite the recommendation by the Working Group, is a general affirmation of the child's right to special protection, care and assistance. This is set out in Article 3 paragraph 2 Convention on the Rights of the Child and is one of the most reiterated principles in other non-child specific human rights documents such as the International Covenant on Civil and Political Rights (Articles 23 and 24) and the International Covenant on Economic Social and Cultural Rights (Article 10). It is a minimum and necessary standard which addresses the special vulnerability of children and their corresponding right to care and protection.

The Working Group Report linked the child's right to special protection to the child's entitlement to enjoy all the rights set out in the Bill of Rights, a clause which is also absent from the Commission's proposals. This provision is important, however, because it recognises that the principle of non-discrimination in the enjoyment of rights (set out in Chapter 4) is not enough to ensure that children are guaranteed those rights as well as adults.

30 Failure to implement this principle was of specific concern to the Committee on the Rights of the Child when it considered the First National Report of the UK in 1995; see note 15, at paras 11 and 12 .

31 See note 15 , at paras 11 and 14 . 


\section{(e) Other children's rights provisions}

It should not be presumed from this necessarily selective analysis of the children's rights provisions in the Bill of Rights, that those provisions not considered here adequately meet international requirements. In particular, provision for the rights of children in the criminal justice, education and health care systems could be strengthened further by relying on international standards in these areas. With regard to the children in conflict with the law, for example, a valuable approach might be to include a general reference to UN standards along the following lines:

The State shall secure to all children in conflict with the law the rights set out in international law. In particular, it undertakes to implement the minimum standards enshrined in the United Nations Guidelines for the Prevention of Juvenile Delinquency, Standard Minimum Rules for the Administration of Juvenile Justice and Rules for the Protection of Juveniles deprived of their Liberty.

This approach might be used to expand in an effective manner the scope of protection offered by the Bill of Rights, while keeping the size of the document to a workable minimum.

\section{IV: CONCLUSIONS}

The fact that the children's rights provisions currently occupy the longest section of the Commission's consultation document acknowledges clearly their importance in this entire process. Moreover, the on-going consultation process may result in additional children's rights being included, such as the right to life, survival and development; the right to freedom of expression and the rights of children in care. The Commission's task in striking an appropriate balance between incorporating the many important international standards and the valid proposals of those engaged in the consultation process, and producing an effective, well-worded document aimed to fulfil the objective of furthering the protection of the rights of everyone in Northern Ireland is extremely difficult. In this regard, however, the following advice may be useful:

A Bill of Rights, which achieved full implementation and the effective guarantee to all children in all areas of their lives of the principles of nondiscrimination, best interests and respect for the views of the child would make an enormous contribution to the lives of children in Northern Ireland. It would stand out as a leading example of its kind worldwide. Moreover, the success of a Bill of Rights must also be determined according to the support which it enjoys among children and young people and their sense of ownership of the final document. To this end, the Commission is encouraged to continue to facilitate the participation of children in the drafting process ${ }^{32}$ and to work towards a Bill of Rights, which represents respect for children's rights both in word and in spirit.

32 The Commission's publication in November 2001 of its child-friendly version of the consultation document is a vital part of this process. 